\title{
Up-scaling of multi-variable flood loss models from objects to land use units at the meso-scale
}

\author{
Heidi Kreibich, Kai Schröter, and Bruno Merz \\ German Research Centre for Geosciences GFZ, Section 5.4 Hydrology, Potsdam, Germany \\ Correspondence to: Heidi Kreibich (heidi.kreibich@gfz-potsdam.de)
}

Published: 12 May 2016

\begin{abstract}
Flood risk management increasingly relies on risk analyses, including loss modelling. Most of the flood loss models usually applied in standard practice have in common that complex damaging processes are described by simple approaches like stage-damage functions. Novel multi-variable models significantly improve loss estimation on the micro-scale and may also be advantageous for large-scale applications. However, more input parameters also reveal additional uncertainty, even more in upscaling procedures for meso-scale applications, where the parameters need to be estimated on a regional area-wide basis.

To gain more knowledge about challenges associated with the up-scaling of multi-variable flood loss models the following approach is applied: Single- and multi-variable micro-scale flood loss models are up-scaled and applied on the meso-scale, namely on basis of ATKIS land-use units. Application and validation is undertaken in 19 municipalities, which were affected during the 2002 flood by the River Mulde in Saxony, Germany by comparison to official loss data provided by the Saxon Relief Bank (SAB).

In the meso-scale case study based model validation, most multi-variable models show smaller errors than the uni-variable stage-damage functions. The results show the suitability of the up-scaling approach, and, in accordance with micro-scale validation studies, that multi-variable models are an improvement in flood loss modelling also on the meso-scale. However, uncertainties remain high, stressing the importance of uncertainty quantification. Thus, the development of probabilistic loss models, like BT-FLEMO used in this study, which inherently provide uncertainty information are the way forward.
\end{abstract}

\section{Introduction}

Losses from natural disasters have dramatically increased during the last few decades and floods have generated the largest economic losses, also in Germany (Kreibich et al., 2014). Flood risk analyses are gaining more and more attention in the fields of flood design, prevention, and riskmanagement (EU flood risk directive 2007/60/EC). Flood risk analyses are performed on different spatial scales (Meyer and Messner, 2005; de Moel et al., 2015): At the micro-scale the assessment is based on single elements at risk. For instance, in order to estimate the loss to a community in case of a certain flood scenario, loss is calculated for each affected object (e.g. building). At the meso-scale the assessment is based on spatial aggregations. Typical aggregation units are land use units, e.g. residential areas. At the macroscale large-scale spatial units are the basis for loss estimation.
Typically, administrative units are used, e.g. municipalities, regions, countries. The classification in micro-, meso- and macro-scale is, on the one hand, related to the spatial extent of the loss assessment. On the other hand, there is a methodological distinction: Meso- and macro-scale approaches differ from micro-scale approaches in their need for aggregation. Loss is assessed for aggregated objects, e.g. land use units. Commonly a bottom-up approach is used, which starts with a detailed analysis and modelling of single elements at risk (micro-scale) and develops an up-scaling procedure for application on basis of land-use units (e.g. Kreibch et al., 2010).

The objective of this study is to gain additional knowledge about challenges associated with the up-scaling of flood loss models, particularly multi-variable loss models. Single- and multi-variable flood loss models are up-scaled to be applied 
on the meso-scale in a test area. Validation is undertaken via comparisons with official loss data.

\section{Loss models}

The following seven loss models, which estimate direct economic loss to residential buildings, are up-scaled to be used at the meso-scale.

The probabilistic, multi-variable model BT-FLEMO developed by Merz et al. (2013) is an ensemble of 200 regression trees, which use the following predictors: water depth, return period, contamination indicator, inundation duration, flow velocity indicator, floor space of building, building value and precautionary measures indicator.

The rule based FLEMOps+r model (Elmer et al., 2010) calculates flood loss using five different classes of water depth, three individual building types, two classes of building quality and three classes of return period (Fig. 1).

The regression tree loss model (RT2) developed by Merz et al. (2013) has eight leaves using the predictors water depth, floor space of building, return period, monthly net income of the household.

The stage-damage function of MURL (2000) calculates the loss ratio (rloss [-]) of residential buildings by the equation rloss $=0.02$ wst, where wst is the water depth $[\mathrm{m}]$. For water levels of more than $5 \mathrm{~m}$ the loss ratio is set to 0.1 (Fig. 1).

The stage-damage function of ICPR (2001) estimates the loss ratios of residential buildings by the relation rloss $=$ $\left(2 \mathrm{wst}^{2}+2 \mathrm{wst}\right) / 100$. Estimated loss ratios $>1$ are set to 1 , i.e. total loss (Fig. 1).

The stage-damage function of HYDROTEC $(2001,2002)$ uses the root function rloss $=(27 \sqrt{\mathrm{wst}}) / 100$. Estimated loss ratios $>1$ are set to 1 (Fig. 1).

The stage-damage function sd-f is taken from Merz et al. (2013) and uses the equation rloss $=0.0142+0.0127 \times$ $\sqrt{(\text { wst } \times 100)}$ (Fig. 1).

\section{Up-scaling approach}

The up-scaling approach of Kreibich et al. (2010) is followed, i.e. the model structures are not changed, but the input variables of the micro-scale loss models are estimated areawide for spatially aggregated meso-scale units. The following data is used to estimate the model-input variables for the test area, i.e. 19 municipalities that were affected by the 2002 flood at the river Mulde in Saxony, Germany.

The inundation patterns including water depths distribution of the 2002 flood in the 19 case study municipalities are taken from Grabbert (2006) and Apel et al. (2007). Return periods are taken from Elmer et al. (2010). Contamination indicator, inundation duration, flow velocity indicator, precautionary measures indicator and monthly net income are estimated on basis of empirical flood damage data collected

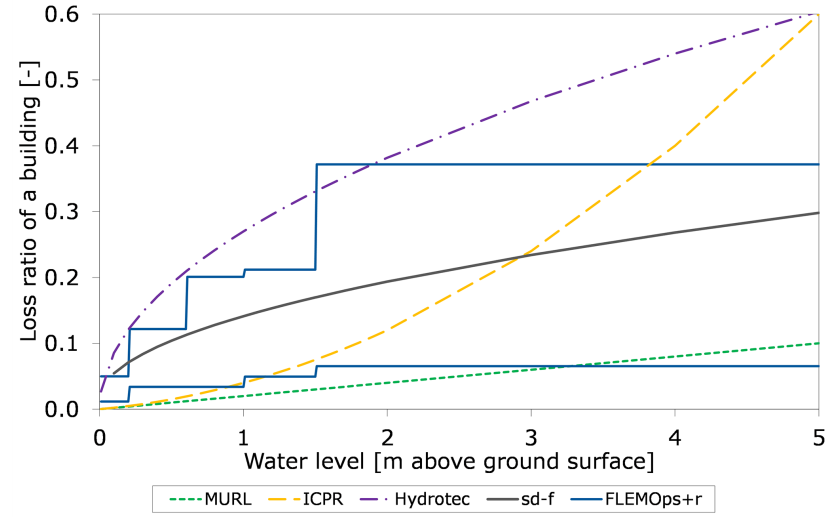

Figure 1. Stage-damage functions as well as upper and lower bounds of the rule based multi-variable model FLEMOps $+\mathrm{r}$ used in this up-scaling study.

via computer aided telephone interviews with households affected by the 2002 flood in the case study area (Thieken et al., 2005). The average floor space of residential buildings as well as the average building value per municipality are taken from the Germany-wide exposure dataset of Kleist et al. (2006). The residential building type composition and the mean residential building quality per municipality are derived following the approach of Thieken et al. (2008).

These meso-scale input variables are estimated on the municipal level, except for water depth and return period, which are given, in a more spatially differentiated format. Water depth is modeled area-wide with $10 \mathrm{~m}$ grid resolution. Return periods are estimated on sub-catchment level. All input variables are processed to be available as raster data sets with a cell size of $10 \mathrm{~m} \times 10 \mathrm{~m}$. For each grid cell, the loss ratio is estimated by applying the seven loss models on basis of the meso-scale input variables. These loss ratios are then multiplied by the specific building value assigned to the corresponding grid cell. Finally, the loss estimates are aggregated per municipality. The specific building values were extracted from Wünsch et al. (2009).

\section{Application and Validation}

Meso-scale model application and validation are conducted in 19 municipalities located at the river Mulde in Saxony, Germany. The area was strongly affected by the 2002 flood. Flood loss was well documented by the Saxon Relief Bank, which was in charge of the loss adjustment and management in Saxony after the flood in 2002.

The above listed seven loss models are used to estimate direct economic losses of residential buildings for the $19 \mathrm{mu}-$ nicipalities of the case study area. The modelled aggregated absolute loss to residential buildings per municipality is compared to the official loss information provided by the Saxon Relief Bank (2005). 
Table 1. Error statistics of meso-scale model performance (MBE: mean bias error, MAE: mean absolute error).

\begin{tabular}{lrrrrrrr}
\hline & MURL & ICPR & HYDROTEC & sd-f & FLEMOps+r & RT2 & BT-FLEMO \\
\hline MBE [Mill. €] & -10.4 & -4.2 & 8.4 & -2.0 & 0.9 & -2.6 & -0.1 \\
MAE [mill. €] & 11.5 & 10.5 & 12.1 & 9.8 & 9.0 & 10.1 & 9.2 \\
\hline
\end{tabular}

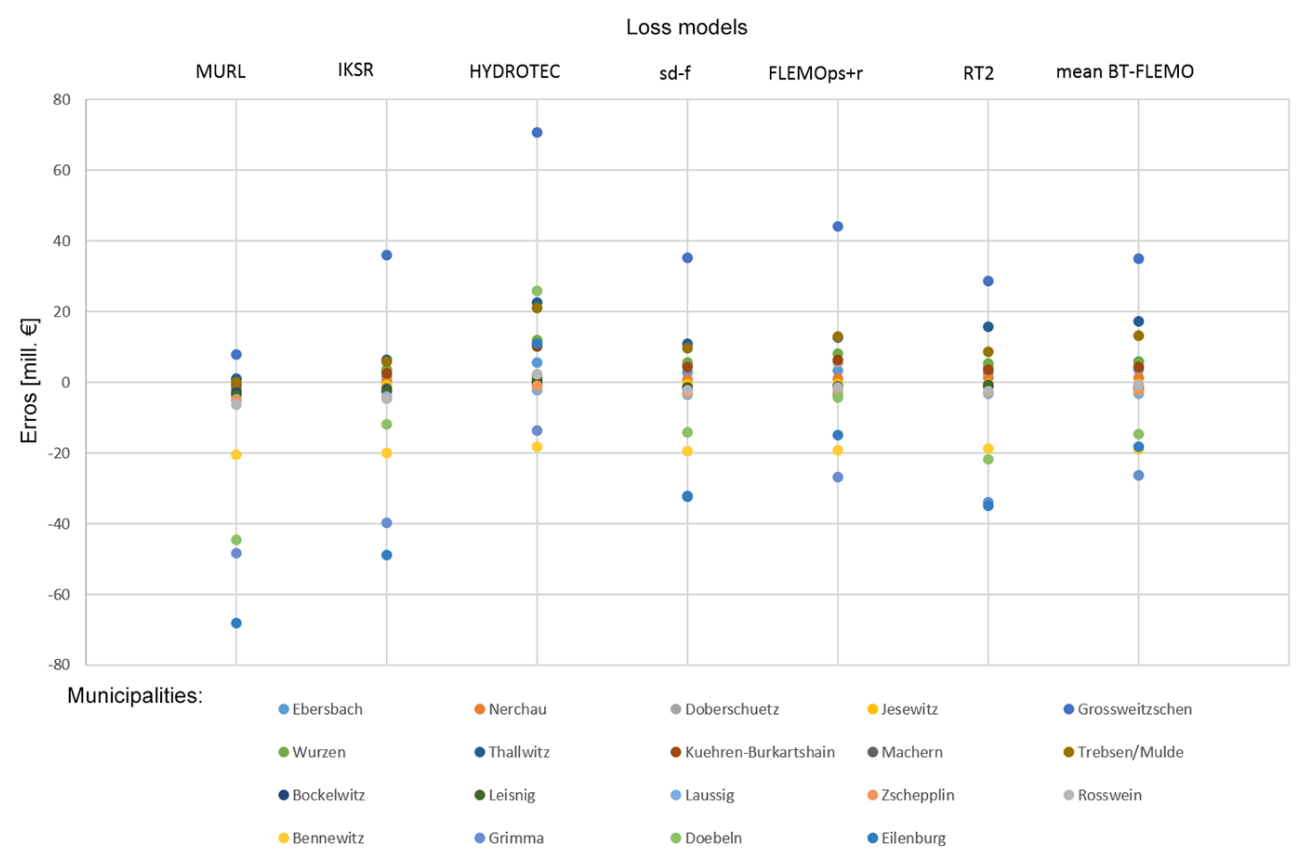

Figure 2. Errors, i.e. estimated loss minus officially reported loss [million euros] for all tested models and municipalities.

\section{Results and Discussion}

The two best performing models in terms of mean absolute error are the multi-variable models FLEMOps+r and BT-FLEMO (Table 1). BT-FLEMO additionally provides a nearly unbiased prediction. The models which were developed on basis of empirical loss data from recent flood events in 2002, 2005 and 2006, namely sd-f, FLEMOps+r, RT2 and BT-FLEMO, perform better than the other models MURL, ICPR, and HYDROTEC which were developed on basis of expert judgement and loss data from floods between 1978 and 1994.

Multi-variable models outperform stage-damage functions and are as such an improvement in flood loss modelling also on the meso-scale. However, the model sd-f with one input variable shows in comparison still relatively good error statistics (Table 1), and is as such also suitable for meso-scale loss estimation. Uncertainties of loss estimation remain high, which underlines the importance of uncertainty quantification. The probabilistic loss model BT-FLEMO is as such a significant advancement.

The error statistics are strongly influenced by five municipalities, which appear particularly problematic for loss es- timation (Fig. 2): Bennewitz, Eilenburg, Grimma and Döbeln where most models underestimate the loss as well as Grossweitzschen where all models overestimate the loss. The different loss models provide coherent results in terms of underestimation in some municipalities and overestimation in others. The within model variation of loss predictions are smaller than within municipalities (Fig. 2). Seifert et al. (2010) reported similar patterns for loss estimation for the commercial sector. They relate large errors in loss estimation to high uncertainties in the exposure estimation, particularly in municipalities with a small fraction of affected companies. This is in accordance with the presented results: smaller errors in loss estimation are obtained for municipalities which incurred larger total loss in comparison to municipalities which incurred a total loss below about EUR 3 million officially reported loss (exception is Bennewitz).

\section{Conclusions}

Multi-variable models outperform stage-damage functions and are as such an improvement in flood loss modelling also on the meso-scale. However, more input variables also reveal additional uncertainty, even more in up-scaling proce- 
dures, where the model input variables are estimated on a regional area-wide basis. Hence, a suitable compromise between model performance and number of variables should be aimed for. Further research should develop more spatially differentiated estimation methods for key input variables used in flood loss estimation at the meso-scale. The use of remote sensing data is a way forward in this respect (Gerl et al., 2014). This study shows that uncertainties of loss estimation remain high. Therefore, thorough validations and uncertainty analyses are necessary for the development of reliable loss models as a basis for application in flood risk studies. The development of probabilistic loss models, possibly with less input variables for an easier meso-scale application, is the way forward.

In municipalities where all loss models significantly overor underestimate the official loss report it is likely that errors and uncertainty result from other sources along the loss estimation chain, e.g. from inundation modelling or exposure estimation. A further source is the uncertainty of the official loss data. These other sources of uncertainty are not addressed in this study. However, comprehensive uncertainty analyses including all components of the flood risk model chain, as for instance undertaken by Apel et al. (2009), should be further developed.

\section{References}

Apel, H., Aronica, G. T., Kreibich, H., and Thieken, A. H.: Evaluation of different modelling strategies for flood risk assessment in urban areas, in: Proceedings of the 32nd Congress of IAHR July 1-6 2007, Venice, Italy, International Association of Hydraulic Engineering \& Research, 2007.

Apel, H., Aronica, G. T., Kreibich, H., and Thieken, A. H.: Flood risk assessments - How detailed do we need to be?, Nat. Hazards, 49, 79-98, 2009.

de Moel, H., Jongman, B., Kreibich, H., Merz, B., PenningRowsell, E., and Ward, P. J.: Flood risk assessments at different spatial scales, Mitigation and Adaptation Strategies for Global Change, 20, 865-890, 2015.

Elmer, F., Thieken, A. H., Pech, I., and Kreibich, H.: Influence of flood frequency on residential building losses, Nat. Hazards Earth Syst. Sci., 10, 2145-2159, doi:10.5194/nhess-10-21452010, 2010.

Gerl, T. M., Bochow, M., and Kreibich, H.: Flood Damage Modeling on the Basis of Urban Structure Mapping Using HighResolution Remote Sensing Data, Water, 6, 2367-2393, 2014.

Grabbert, J.-H.: Analyse der schadensbeeinflussenden Faktoren des Hochwassers 2002 und Ableitung eines mesoskaligen Abschätzungsmodells für Wohngebädeschäden [Analysis of parameters influencing loss during the flood event 2002 and development of a meso-scale estimation model for residential building damages], Unpublished thesis, University of Potsdam, 2006.
HYDROTEC: Hochwasser-Aktionsplan Angerbach [Flood action plan for the river Angerbach]. Teil I: Berichte und Anlagen, National Environmental Agency of the City of Düsseldorf, Aachen, Germany, 2001.

HYDROTEC: Hochwasser-Aktionsplan Lippe [Flood action plan for the river Lippe]. Teil I: Berichte und Anlagen, National Environmental Agency of the City of Lippstadt, Aachen, Germany, 2002.

ICPR (International Commission for the Protection of the Rhine): Rhine-Atlas, ICPR, Koblenz, available at: http://www.rheinatlas. de, 2001.

Kleist, L., Thieken, A. H., Köhler, P., Müller, M., Seifert, I., Borst, D., and Werner, U.: Estimation of the regional stock of residential buildings as a basis for a comparative risk assessment in Germany, Nat. Hazards Earth Syst. Sci., 6, 541-552, doi:10.5194/nhess-6-541-2006, 2006.

Kreibich, H., Seifert, I., Merz, B., and Thieken, A. H.: Development of FLEMOcs - A new model for the estimation of flood losses in companies, Hydrolog. Sci. J., 55, 1302-1314, 2010.

Kreibich, H., Bubeck, P., Kunz, M., Mahlke, H., Parolai, S., Khazai, B., Daniell, J., Lakes, T., and Schröter, K.: A review of multiple natural hazards and risks in Germany, Nat. Hazards, 74, 22792304, 2014.

Merz, B., Kreibich, H., and Lall, U.: Multi-variate flood damage assessment: a tree-based data-mining approach, Nat. Hazards Earth Syst. Sci., 13, 53-64, doi:10.5194/nhess-13-53-2013, 2013.

Meyer, V. and Messner, F.: National Flood Damage Evaluation Methods: A Review of Applied Methods in England, the Netherlands, the Czech Republic and Germany, UFZ-Discussion Papers, www.floodsite.net, 2005.

MURL (Ministerium für Umwelt, Raumordnung und Landwirtschaft des Landes Nordrhein-Westfalen): Potentielle Hochwasserschäden am Rhein in Nordrhein-Westfalen, Düsseldorf, 2000.

Saxon Relief Bank (SAB): Schäden durch das Hochwasser 2002, Angaben aus der Fördermitteldatenbank [Damages of the flood 2002. Data from the Compensation Data Bank], February, 2005.

Seifert, I., Kreibich, H., Merz, B., and Thieken, A. H.: Application and validation of FLEMOcs - a flood loss estimation model for the commercial sector, Hydrolog. Sci. J., 55, 1315-1324, 2010.

Thieken, A. H., Müller, M., Kreibich, H., and Merz, B.: Flood damage and influencing factors: New insights from the $\mathrm{Au}-$ gust 2002 flood in Germany, Water Resour. Res., 41, W12430, doi:10.1029/2005WR004177, 2005.

Thieken, A. H., Olschewski, A., Kreibich, H., Kobsch, S., and Merz, B.: Development and evaluation of FLEMOps - a new Flood Loss Estimation MOdel for the private sector, in: Flood Recovery, Innovation and Response, edited by: Proverbs, D., Brebbia, C. A., and Penning-Rowsell, E., WIT Press, 315-324, 2008.

Wünsch, A., Herrmann, U., Kreibich, H., and Thieken, A. H.: The Role of Disaggregation of Asset Values in Flood Loss Estimation: A Comparison of Different Modeling Approaches at the Mulde River, Germany, Environ. Manage., 44, 524-541, 2009. 